\title{
The Comparison of Optimal Portfolio Formation Analysis with Single Index Model and Capital Asset Pricing Model in Making Investment Decision
}

\author{
Nurul Avriyanti Sholehah, Yul Tito Permadhy, and Fitri Yetty
}

\begin{abstract}
This research aims to find out the portfolio comparison that results from Single Index Model and Capital Asset Pricing Model methods, also portfolio performance evaluation results from Sharpe Index, Treynor Index, and Jensen Index on stocks listed in the LQ45 Index from 20172019. Samples taken consisted of 17 shares of companies listed on the LQ45 Index successively and it has a positive average return. Analysis using the Single Index Model method produces an optimal portfolio consisting of 6 shares. Whereas the Capital Asset Pricing Model method produces an efficient portfolio consisted of 13 shares. Portfolio performance evaluation created from both methods results from the rank of shares from each portfolio also has a positive average index, that means shares consisted of these portfolios are worth to be invested.
\end{abstract}

Index Terms - Portfolio, Single Index Model, Capital Asset Pricing Model, Portfolio Performance Evaluation.

\section{INTRODUCTION}

Investment is an activity of investors by expecting rewards in the form of dividends or obtaining expected returns. Determination of what stocks are most appropriate for investment needs to be analyzed by each investor in advance by creating an optimal stock portfolio. Stock portfolio analysis can be a basis for investor consideration before investing by combining several stocks from various companies for investment purposes.

\subsection{9 .075}

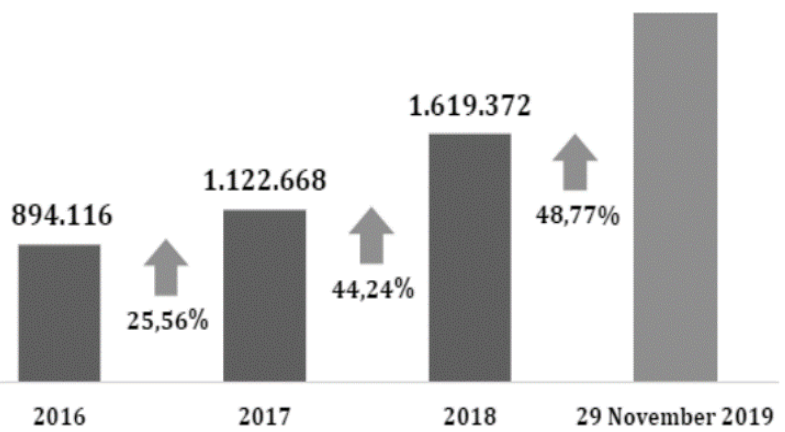

Fig. 1. Growth Amount of Single Investor Identification [13].

Published on August 21, 2020.

Nurul Avriyanti Sholehah, University of Pembangunan Nasional Veteran Jakarta, Indonesia

(e-mail: nurulavriyanti27@gmail.com).

Yul Tito Permadhy, University of Pembangunan Nasional Veteran Jakarta, Indonesia

(e-mail: madhyyul@yahoo.com).

Fitri Yetty, University of Pembangunan Nasional Veteran Jakarta, Indonesia

(e-mail: fitriyetty_61@yahoo.com).
Based on the graph above shows the growth in the number of investors during the last few years, proves the level of interest in investment activities by the Indonesian people. The increasing number of SIDs is registered, meaning that the bigger the frequency of transactions that occur in the Indonesian capital market. This has a positive impact on the development of the capital market in Indonesia.

Before an investor decides to invest, the investor needs to determine how much of the expected return obtained in the capital market first. However, investors cannot ensure that the expected rate of return will be earned by the return that will be received at the end of the period, which may be higher or lower than expected. Stock returns that generate profits. While stock returns that provide losses (capital loss) means that stock returns are negative. This means there is a factor called risk.

In the portfolio, investors can determine the expected return and risk level with various portfolio analysis approach. In this study, the method used in determining the portfolio used is the Single Index Model and the Capital Asset Pricing Model. SIM method has an assumption that market index movements have a general relationship with the stock prices of each company. But based on several studies, the movement of the market index is influenced by many things. This was corrected and perfected by the CAPM method. CAPM method is used in analyzing the portfolio to calculate the expected rate of return of risky assets with the risk of assets in balanced market conditions.

This study uses LQ45 index company shares to be investigated where company stocks with good financial performance classified in the LQ45 index. In other words, the company is very able to pay off obligations through assets owned and has a large value for the company if calculated from the total shares outstanding in the market. But stocks in the LQ45 index are classified as liquid because of the high number of transaction values, so investors who want to invest in the LQ45 index must pay attention to the rate of return and the level of risk that may occur. The closing price of the LQ45 Index which has increased and decreased each month indicates that in addition to calculating the expected return to be obtained, investors must also be careful in calculating investment risk.

From the background described above, the writer takes the research about The Comparison of Optimal Portfolio Formation Analysis with Single Index Model and Capital Asset Pricing Model In Making Investment Decision.

Based on the background that has been explained, the formulation of the problem in this study is how the portfolio 
results are formed by the Single Index Model and Capital Asset Pricing methods on LQ45 Index stocks also how the results of the performance evaluation of each portfolio are formed.

Based on the background and formulation of the problem above, it can be concluded the purpose of the study is to find out the results of the portfolio formed by the Single Index Model and the Capital Asset Pricing Model on LQ45 Index shares and the results of the performance evaluation of each portfolio.

The results of this study are expected to be useful in the practical aspect of conceptual insight and becoming a useful reference material on capital markets, portfolios, investments, and portfolio analysis methods especially the Single Index Model and the Capital Asset Pricing Model. Also for shareholders that can provide a benchmark of knowledge in understanding optimal portfolios and can provide a high level of expected return with a small level of risk, so that investors can be considered before making investment decisions and the last is a trigger to increase the interest of potential investors in investing in the capital market so that it will increase the number of investors who are increasingly developing in the capital market.

\section{LITERATURE REVIEW}

The first modern portfolio theory was put forward in 1952 by Harry Markowitz, this theory aims to obtain optimal profits by dealing with certain risks by combining various stocks into one portfolio. In his theory, Markowitz has the assumption that investment decision making is based on expected return and the level of portfolio risk. Where the expected return is calculated by the average arithmetic (mean) expected return of each asset. While the level of risk is calculated using the concept of standard deviation or variance.

A portfolio can be defined as investor discretion in preparing investment portfolios that are suitable for risk and investment objectives. Portfolios are composed of several types of investment to obtain profits by considering the adjusted risk that Investors can choose various types of investments to determine the portfolio. Portfolios are divided into optimal portfolios and efficient portfolios. Efficient portfolio is a portfolio that offers the greatest expected return with certain risks or offers the lowest level of risk with a certain expected return. Optimal portfolio is the portfolio that gives the optimal expected return with the smallest risk from the arrangement of investor choices [5].

The LQ45 index consists of 45 shares on the Indonesia Stock Exchange (IDX) with the highest level of liquidity and the largest market capitalization that passed the selection based on several criteria. Stock exchanges monitor the development of the performance of each share included in the LQ45 index. Shares are changed every six months, at the beginning of February and August. If there are shares that do not fit the LQ45 index selection criteria, then these shares will be excluded from the index calculation and will be replaced by other shares that match the criteria.

The Single Index Model (SIM) or commonly known as the market model is one of the three major theories in finance and investment. This method was proposed by
William Sharpe (1963) which was caused by problems regarding portfolio calculations using the Markowitz method which was considered quite complicated because it involved many variants and covariance. Therefore, the Single Index Model (SIM) is the answer to simplify calculations on the Markowitz model. In the Single Index Model (SIM) there are several variables in optimal portfolio calculations, particularly expected stock and market returns, variance, covariance, alpha, beta, residual error variance, excess return to beta (ERB), cut-off rate (Ci), and cut-off point $\left(C^{*}\right)$. Shares that can be classified into this portfolio if the ERB value of shares must be equal to or greater than the cut-off point value.

The Capital Asset Pricing Model (CAPM) was first introduced by Sharpe, Lintner, and Mossin in the 1960s. According to him, CAPM is a model that combines the expected return of risky assets to the risk of assets in a balanced market condition [5]. This model helps investors understand how to determine the relevant risk for an asset, as well as the relationship between expected return and the expected risk for an asset in a market condition in a balanced condition. In this condition, investors will not get extra returns from the price level formed, including with investors who trade so that it will encourage investors to choose market portfolios consisting of risky assets. CAPM becomes a model that can predict reality in a complex market.

After an investor makes a portfolio, the investor needs to evaluate the performance of the portfolio. In its evaluation, portfolio performance is evaluated by two main points. The first point is evaluating whether the portfolio returns that have been formed can provide returns more than what has been used as a benchmark (benchmark). The second point is evaluating whether the return obtained is following the level of risk borne. This is necessary because to know portfolio performance, investors can not only be guided by the rate of return but also must pay attention to other factors, such as risk level. In measuring the performance of this portfolio, there's several measures, namely the Sharpe index, the Treynor index, and the Jensen index.

Sharpe Index or commonly called the reward to variability ratio. In the Sharpe index, total risk (a combination of systematic risk and unsystematic risk) becomes a risk that is considered relevant, meaning that the portfolio has not been well diversified. This index is calculated by dividing the portfolio risk premium by the standard deviation. Sharpe Index or commonly called the reward to variability ratio assumed that the portfolio is well diversified or systematic risk is considered to be a relevant risk, meaning that the return of a portfolio is almost entirely influenced by market returns.. The Jensen index is an index that illustrates the difference between the actual rate of return of a portfolio and the expected rate of return if a portfolio located on the capital market line. 


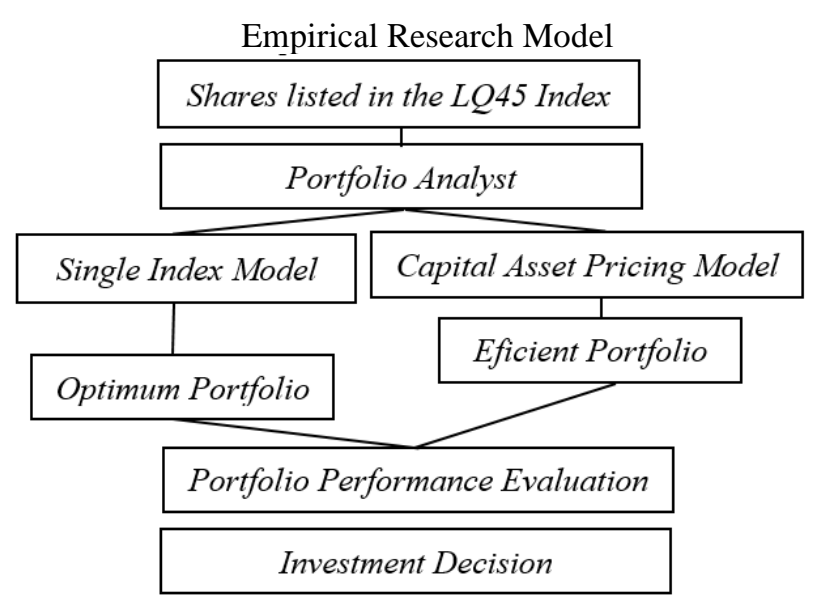

Fig. 2. Thinking Framework.

\section{RESEARCH METHODOLOGY}

A. Research Variables and Operational Definition Variables

\section{Single Index Model}

The following is an operational definition in using the Single Index Model (SIM) method:

1) Excess Return to Beta

$$
E R B=\frac{E(R i)-R f r}{\beta}
$$

where:

$\mathrm{ERB}=$ Excess return to beta of a stock

$\mathrm{E}(\mathrm{Ri})=$ Expected return of a stock

$\mathrm{Rfr}=$ Risk free rate

$\beta=$ Beta

2) Cut-off Point

$$
C i=\frac{\sigma m^{2} \sum_{i=1}^{i} \frac{[E(R i)-R f r]}{\sigma e i^{2}}}{1+\sigma m^{2} \sum_{j=1}^{i} \frac{\beta^{2}}{\sigma e i^{2}}}
$$

where:

$\mathrm{Ci}=$ Cut-off rate

$\mathrm{E}(\mathrm{Ri})=$ Expected return of a stock

$\mathrm{Rfr}=$ Risk free rate

$\mathrm{Bi}=$ Beta

$\sigma e i^{2}=$ Variance residual error

$\sigma \mathrm{m}^{2}=$ Variance of stock returns

3) Zi dan $\mathrm{Wi}$

$$
\begin{aligned}
& Z i=\frac{\beta}{\sigma e i^{2}}\left(E R B-C^{*}\right) \\
& W i=\frac{Z i}{\sum_{j=1}^{i} Z i}
\end{aligned}
$$

where:

$\beta=$ Beta

$\sigma \mathrm{ei}^{2}=$ Variance residual error

$\mathrm{ERB}=$ Excess return to beta

$C^{*}=$ Unique cut-off point value

$\mathrm{Zi}=$ Stock weighted scale
4) Expected Return of Portfolio

$$
E(R p)=\alpha_{p}+\beta_{p} \bullet E(R m)
$$

where:

$\alpha_{\mathrm{p}}=$ alpha portfolio

$\beta_{\mathrm{p}}=$ beta portfolio

$\mathrm{E}(\mathrm{Rm})=$ Expected return of market

5) Risk of Portfolio

$$
\sigma_{p}^{2}=\beta_{p}^{2}+\sigma m^{2}+\left(\sum_{i=1}^{n} W i \cdot \sigma e i\right)^{2}
$$

$\sigma_{\mathrm{p}}^{2}=$ portfolio risk

$\beta_{\mathrm{p}}=$ beta portfolio

$\sigma \mathrm{m}^{2}=$ market return variance

$\sigma \mathrm{ei}^{2}=$ stock return variance

\section{Capital Asset Pricing Model}

The following is an operational definition in using the Capital Asset Pricing Model method:

$$
\begin{aligned}
& \text { 1) Beta } \\
& \beta=\frac{\text { oim }}{\sigma m^{2}}
\end{aligned}
$$

$\beta=$ Beta

$\sigma \mathrm{im}=$ Covariance

$\sigma \mathrm{m}^{2}=$ Variance of stock returns

2) Expected Return

$$
E(R i)=R f r+\beta[E(R m)-R f r]
$$

where:

$\mathrm{E}(\mathrm{Ri})=$ Expected return of individuals

$\mathrm{Rfr}=$ Risk free rate of return

$\beta=$ Beta stock

3) Security Market Line (SML)

Security Market Line (SML) is a line model that describes the relationship between the expected rate of return and systematic risk.

\section{Portfolio Performance Evaluation}

Evaluation of portfolio performance can be measured through 3 indexes, as follows:

1) Sharpe Index

$$
R V A=\frac{\overline{R i}-R f r}{\sigma T R}
$$

where:

$\mathrm{RVA}=$ Reward to variability ratio or sharpe index

$\mathrm{Ri}=$ The average portfolio return of a stock for a period

$\mathrm{Rfr}=$ Average risk-free rate for one period

$\sigma \mathrm{TR}=$ Standard deviation

$$
\text { 2) Treynor Index }
$$

$$
R V O=\frac{\overline{R i}-R f r}{\beta}
$$

where:

$\mathrm{RVO}=\mathrm{Reward}$ to volatility ratio or treynor index

$\mathrm{Ri}=$ The average portfolio return of a stock for a period 
$\mathrm{Rfr}=$ Average risk-free rate for one period

$\beta=$ Beta

3) Jensen Index

$\alpha=$ average return - expected return

where:

$\alpha+=$ Alpha or Jensen's portfolio index

\section{B. Determination of Population and Samples}

\section{Population}

In this study, the population used is the company's shares which are counted in the LQ45 index during the study period in 2017 - 2019. With the population determined in the criteria, there are 32 companies selected.

\section{Sample}

In this study, the sample used was the purposive sampling method. With these criteria as follows:

1) The sample is a company stock classified in the LQ45 index during the study period from 2017 to 2019.

2) Shares included in the optimal portfolio analysis calculation are stocks that have a positive expected return. Stocks with a positive expected return deserve to be a choice in investing.

\section{Data Types and Sources}

This research uses secondary data types. Secondary data used in this study are companies that are included in the LQ45 index during the 2017-2019 period, closing prices of the LQ45 index company's shares in each month from January 2017 to July 2019, Composite Stock Price Index of the LQ45 index, Certificate interest rates Bank Indonesia. In this study, data collected about the LQ45 index are accessed through three website sources, specifically www.idx.co.id, finance.yahoo.com, and www.bi.go.id.

\section{Method of Collecting Data}

This study uses data collected for analysis using two methods. First is the literature method in which information data is obtained from reference books and previous research journals, which furthermore information data will be used as a guide in this study. Second, the documentation method is a method by collecting all data information that has been published and presented in the form of graphs and tables by companies that are included in the research from the sources of the sites accessed, www.idx.co.id, finance.yahoo.com, and www.bi.go.id.

\section{Data Analyst Techniques}

In conducting data analysis, Ms. Excel program is a tool for calculate optimal portfolio formation analysis. The steps to calculate the analysis using the Single Index Model (SIM) are as follows:

a. Collecting data on the closing price of shares in each month which is classified in the LQ45 index for the 2017 2019 period

b. Calculates the realized return of each stock and the realized market return

c. Calculate the expected rate of return for each stock and market
d. Calculate each variant of the stock and market
e. Count covariance
f. Calculate beta $(\beta)$
g. Calculate alpha $(\alpha)$
h. Calculating residual error variance.

i. Determine excess return to beta (ERB)

j. Calculates the cut-off rate $(\mathrm{Ci})$

$\mathrm{k}$. Determine the unique-cut-off point $(\mathrm{C} *)$

1. Determine the optimal portfolio with the terms ERB> $\mathrm{C} *$

m. Calculate the weighted scale of shares $(\mathrm{Zi})$ and optimal portfolio proportion (Wi)

n. Calculate the expected return portfolio and portfolio risk

Second method is CAPM. The stages in the CAPM calculation are:

a. Collect historical closing price data from all shares calculated in the LQ45 index

b. Calculates the realized return rate of stock and market

c. Calculate the expected level of return from a market

d. Calculate the risk free rate

e. Calculate covariance value

f. Calculates the value of variance

g. Calculate beta values

h. Calculate the expected rate of return through the Capital Asset Pricing Model (CAPM) method.

i. Describe the results by drawing a Security Market Line (SML) chart.

j. Determine an efficient portfolio with in terms $\mathrm{Ri}>\mathrm{E}$ (Ri)

\section{RESEARCH FINDING AND DISCUSSION}

\section{A. Result Data Description}

TABLE I: RESULT OF DATA DESCRIPTION

\begin{tabular}{clc}
\hline \hline No & \multicolumn{1}{c}{ Information } & Total \\
\hline 1 & $\begin{array}{l}\text { Companies included in the LQ45 index on the IDX } \\
\text { during the 2017-2019 period }\end{array}$ & 45 \\
\hline 2 & $\begin{array}{l}\text { Companies that are not continuously included in the } \\
\text { LQ45 index during 2017-2019 }\end{array}$ & $(19)$ \\
\hline 3 & The average rate of return that is negative & (9) \\
\hline 4 & Total sample & \\
\hline \hline Source: idx.co.id.
\end{tabular}

The table presented above explains that 17 companies fit the criteria so that they can be used in calculating the optimal portfolio formation based on the Single Index Model (SIM) and the Capital Asset Pricing Model (CAPM) method.

\section{B. Data Analyst}

In this study, the data analysis used is the Single Index Model (SIM) and the Capital Asset Pricing Model (CAPM), and the evaluation of portfolio performance using the Sharpe index, Treynor index, and Jensen index.

\section{Single Index Model (SIM)}

a. Expected Return, Variance, and Standard Deviation of Stock

The expected return is calculated by the average of returns of each stock. The expected return of stocks that are positive in value will be included calculation.

TABLE II: EXPECTED RETURN, VARIANCE, AND STANDARD DEVIATION 


\begin{tabular}{ccccc}
\hline \hline No. & $\begin{array}{c}\text { Stock } \\
\text { Code }\end{array}$ & $\mathbf{E}(\mathbf{R i})$ & $\boldsymbol{\sigma i}^{2}$ & $\boldsymbol{\sigma i}$ \\
\hline 1 & BBCA & 0.024622 & 0.003755 & 0.041895 \\
\hline 2 & BBNI & 0.016436 & 0.006619 & 0.081354 \\
\hline 3 & BBRI & 0.023458 & 0.003359 & 0.057961 \\
\hline 4 & BBTN & 0.014189 & 0.011177 & 0.105722 \\
\hline 5 & BMRI & 0.013524 & 0.001725 & 0.041528 \\
\hline 6 & GGRM & 0.008409 & 0.003460 & 0.058822 \\
\hline 7 & ICBP & 0.009029 & 0.001859 & 0.043113 \\
\hline 8 & INCO & 0.017460 & 0.019302 & 0.138930 \\
\hline 9 & INTP & 0.019171 & 0.011094 & 0.105329 \\
\hline 10 & JSMR & 0.009445 & 0.005750 & 0.075831 \\
\hline 11 & KLBF & 0.001800 & 0.002660 & 0.051572 \\
\hline 12 & MNCN & 0.003373 & 0.020249 & 0.142299 \\
\hline 13 & PTBA & 0.012271 & 0.014090 & 0.118700 \\
\hline 14 & TLKM & 0.005097 & 0.003059 & 0.055304 \\
\hline 15 & UNTR & 0.007309 & 0.005703 & 0.075520 \\
\hline 16 & UNVR & 0.003180 & 0.002620 & 0.051190 \\
\hline 17 & WIKA & 0.005586 & 0.018729 & 0.136854 \\
\hline \hline
\end{tabular}

Source: Ms. Excel (Data Processed).

From the 17 selected company shares, BBCA (Bank Central Asia Tbk.) is the highest expected return, and KLBF (Kalbe Farma Tbk.) is the lowest expected rate of return. MNCN (Media Nusantara Citra Tbk.) is the highest variance and BMRI (Bank Mandiri Tbk.) is the lowest variance.

b. Market Return

A market return is calculated by the difference in marketclosing price in the month $\mathrm{t}$ and the previous mointh then divided by the closing price of shares in the month $\mathrm{t}$.

TABLE III: EXPECTED RETURN, VARIANCE, AND STANDARD DEVIATION MARKET

Source: Ms. Excel (data processed).

\begin{tabular}{ccc}
\multicolumn{3}{c}{ MARKET } \\
\hline \hline $\mathbf{E}(\mathbf{R m})$ & $\boldsymbol{\sigma m}^{\mathbf{2}}$ & $\boldsymbol{\sigma m}$ \\
\hline 0.005935 & 0.001663 & 0.040779 \\
\hline \hline (data processed)
\end{tabular}

The expected return of market is $0.5935 \%$, market variance is $0.1663 \%$, and standard deviations of 0.040779 or $4.0779 \%$.

c. Covariance, Beta, Alpha, and Variance Error Residual

Covariance is the correlation between individual stock returns and market returns. Beta is calculated by covariance of individual shares divided by market variance. Variance Error Residual is calculated by the difference between the variance with the result of beta squared times the market variance.

TABLE IV: COVARIANCE, BETA, ALPHA, AND VARIANCE ERROR RESIDUAL

\begin{tabular}{cccccc}
\hline \hline No & $\begin{array}{c}\text { Stock } \\
\text { Code }\end{array}$ & $\boldsymbol{\sigma i m}$ & $\boldsymbol{\beta i}$ & $\boldsymbol{\alpha i}$ & $\boldsymbol{\sigma e i}^{2}$ \\
\hline 1 & BBCA & 0.000736 & 0.442527 & 0.021995 & 0.001430 \\
\hline 2 & BBNI & 0.002201 & 1.323852 & 0.008579 & 0.003704 \\
\hline 3 & BBRI & 0.001253 & 0.753353 & 0.018986 & 0.002416 \\
\hline 4 & BBTN & 0.002165 & 1.301929 & 0.006462 & 0.008358 \\
\hline 5 & BMRI & 0.000934 & 0.561371 & 0.010192 & 0.001201 \\
\hline 6 & GGRM & 0.001277 & 0.767870 & 0.003852 & 0.002479 \\
\hline 7 & ICBP & 0.000569 & 0.342231 & 0.006998 & 0.001664 \\
\hline 8 & INCO & 0.001700 & 1.022320 & 0.011393 & 0.017564 \\
\hline 9 & INTP & 0.001216 & 0.731518 & 0.014829 & 0.010204 \\
\hline 10 & JSMR & 0.001100 & 0.661702 & 0.005518 & 0.005022 \\
\hline 11 & KLBF & 0.001315 & 0.790906 & -0.002894 & 0.001619 \\
\hline 12 & MNCN & 0.000522 & 0.313952 & 0.001510 & 0.020085 \\
\hline 13 & PTBA & 0.000253 & 0.152152 & 0.011368 & 0.014051 \\
\hline 14 & TLKM & -0.000017 & -0.010215 & 0.005158 & 0.003058 \\
\hline 15 & UNTR & 0.000791 & 0.475537 & 0.004487 & 0.005327 \\
\hline 16 & UNVR & 0.001063 & 0.639055 & -0.000612 & 0.001941 \\
\hline 17 & WIKA & 0.002100 & 1.263023 & -0.001910 & 0.016076 \\
\hline \hline See Ms. Excel (data processed). & & &
\end{tabular}

d. Excess Return to Beta, Cut-Off Rate, and Cut-Off Point

ERB, cut-off rate, and cut-off point is used to sort stocks into optimal portfolios. The cut-off rate is calculated by the value of the market variance times the sum Ai from each share $(\Sigma \mathrm{Ai})$ divided by one plus the market variance multiplied by the sum $\mathrm{Bi}$ of each share $(\Sigma \mathrm{Bi})$.

\begin{tabular}{cccccc}
\multicolumn{6}{c}{ TABLE V: ERB, CUT-OFF RATE, AND CUT-OFF POINT } \\
\hline \hline No & $\begin{array}{c}\text { Stock } \\
\text { Code }\end{array}$ & ERB & & Ci & C* \\
\hline 1 & PTBA & 0.052732 & $>$ & 0.000144 & 0.013803 \\
\hline 2 & BBCA & 0.046040 & $>$ & 0.008640 & 0.013803 \\
\hline 3 & BBRI & 0.025499 & $>$ & 0.012703 & 0.013803 \\
\hline 4 & INTP & 0.020400 & $>$ & 0.013096 & 0.013803 \\
\hline 5 & BMRI & 0.016524 & $>$ & 0.013794 & 0.013803 \\
\hline 6 & ICBP & 0.013970 & $>$ & 0.013803 & 0.013803 \\
\hline 7 & INCO & 0.012924 & $<$ & 0.013766 & 0.013803 \\
\hline 8 & BBNI & 0.009207 & $<$ & 0.012626 & 0.013803 \\
\hline 9 & JSMR & 0.007854 & $<$ & 0.012416 & 0.013803 \\
\hline 10 & BBTN & 0.007636 & $<$ & 0.011972 & 0.013803 \\
\hline 11 & UNTR & 0.006438 & $<$ & 0.011867 & 0.013803 \\
\hline 12 & GGRM & 0.005419 & $<$ & 0.011244 & 0.013803 \\
\hline 13 & WIKA & 0.001059 & $<$ & 0.010850 & 0.013803 \\
\hline \hline Source: Ms. Excel (data processed). & & \\
\hline
\end{tabular}

Based on the table, the highest value of $\mathrm{Ci}$ being the cutoff point is 0.013803 of ICBP (Indofood CBP Tbk.). There are 6 shares of companies that have ERB> $\mathrm{C} *$, namely PTBA, BBCA, BBRI, INTP, MBRI, and ICBP shares. This means that the six stocks will be included in the optimal stock portfolio.

e. Proportion of optimal portfolio funds

Determining the proportion of funds calculated using the variables $\mathrm{Zi}$ and $\mathrm{Wi}$. The following are the results of $\mathrm{Zi}$ and $\mathrm{Wi}$ in the analysis of the optimal proportion of stock portfolio funds.

TABLE VI: ZI AND WI INDIVIDUAL SHARES

\begin{tabular}{ccccc}
\hline \hline No & $\begin{array}{c}\text { Stock } \\
\text { Code }\end{array}$ & $\mathbf{Z i}$ & $\mathbf{W i}$ & $\mathbf{W i \%}$ \\
\hline 1 & PTBA & 0.421545 & 0.026632 & $2.66 \%$ \\
\hline 2 & BBCA & 9.979276 & 0.630468 & $63.05 \%$ \\
\hline 3 & BBRI & 3.647540 & 0.230443 & $23.04 \%$ \\
\hline 4 & INTP & 0.472953 & 0.029880 & $2.99 \%$ \\
\hline 5 & BMRI & 1.272608 & 0.080401 & $8.04 \%$ \\
\hline 6 & ICBP & 0.034433 & 0.002175 & $0.22 \%$ \\
\hline Jumlah & $\mathbf{1 5 . 8 2 8 3 5 5}$ & $\mathbf{1}$ & $\mathbf{1 0 0 . 0 0 \%}$ \\
\hline \hline
\end{tabular}

Source: Ms. Excel (data processed).

Based on the table above, the largest proportion of funds from the optimal portfolio of shares is BBCA (Bank Central Asia Tbk.) Shares of $63.05 \%$ and the smallest is ICBP (Indofood CBP Sukses Makmur Tbk.) shares of $0.22 \%$.

f. Expected Return and Optimal Portfolio Risk

Apart from the proportion of funds that must be spent by investors for the established portfolio, investors also need to know the level of expected return and the level of risk generated in a portfolio.

Based on the table blow, it shows that the level of expected return generated by the optimal portfolio is $2.29 \%$ and the risk level is $0.319 \%$. 
TABLE VII: EXPECTED RETURN AND PORTFOLIO RISK LEVEL

\begin{tabular}{cccccc}
\hline \hline No & $\begin{array}{c}\text { Stock } \\
\text { Code }\end{array}$ & $\mathbf{W i}$ & $\boldsymbol{\alpha}_{\mathbf{p}}$ & $\boldsymbol{\beta}_{\mathbf{p}}$ & $\boldsymbol{\sigma i}_{\mathbf{p}}{ }^{2}$ \\
\hline 1 & PTBA & 0.026632 & 0.000303 & 0.004052 & 0.000375 \\
\hline 2 & BBCA & 0.630468 & 0.013867 & 0.279000 & 0.001107 \\
\hline 3 & BBRI & 0.230443 & 0.004375 & 0.173605 & 0.000774 \\
\hline 4 & INTP & 0.029880 & 0.000443 & 0.021858 & 0.000331 \\
\hline 5 & BMRI & 0.080401 & 0.000819 & 0.045134 & 0.000139 \\
\hline 6 & ICBP & 0.002175 & 0.000015 & 0.000744 & 0.000004 \\
\hline Jumlah & 1.000000 & 0.019823 & 0.524394 & 0.002730 \\
\hline Expected Return Pasar E(Rm) & & 0.005935 \\
\hline Expected Return Portofolio $\mathbf{E}\left(\mathbf{R}_{\mathbf{p}}\right)$ & & 0.022935 \\
\hline \multicolumn{7}{l}{ Varians Market $\left(\boldsymbol{\sigma m}^{\mathbf{2}}\right)$} \\
\hline
\end{tabular}

Source: Ms. Excel (data processed).

\section{Capital Asset Pricing Model}

a. Realized Return, Expected Return Market, Beta, and Expected Return Shares.

Realized return on shares shows the actual amount of profits that investors get after investing. The realized return calculated by dividing the difference between the closing price of shares this month and the previous month divided by the closing price of shares in the previous month.

Market returns are based on stock index price movements. The market rate of return is calculated as the difference between the current and previous month's market closing prices divided by the previous month's market closing prices.

Beta can describe the relationship between stock returns and market returns. This is because beta is the result of a comparison between stock covariance and market variants.

The expected return is the amount of profit expected by investors when investing. In obtaining the expected return value, there are three variables required in the calculation, namely the market rate of return $[\mathrm{E}(\mathrm{Rm})]$, the risk free rate (Rf), and beta $(\beta)$.

TABLE VIII: REALIZED RETURN, EXPECTED RETURN MARKET, BETA, AND EXPECTED RETURN SHARES

\begin{tabular}{cccccc}
\hline \hline No & $\begin{array}{c}\text { Stock } \\
\text { Code }\end{array}$ & $\mathbf{R f}$ & $\boldsymbol{\beta i}$ & $\mathbf{E}(\mathbf{R m})$ & $\mathbf{E}(\mathbf{R i})$ \\
\hline 1 & BBCA & 0.004248 & 0.442527 & 0.005935 & 0.004994 \\
\hline 2 & BBNI & 0.004248 & 1.323852 & 0.005935 & 0.006481 \\
\hline 3 & BBRI & 0.004248 & 0.753353 & 0.005935 & 0.005519 \\
\hline 4 & BBTN & 0.004248 & 1.301929 & 0.005935 & 0.006444 \\
\hline 5 & BMRI & 0.004248 & 0.561371 & 0.005935 & 0.005195 \\
\hline 6 & GGRM & 0.004248 & 0.767870 & 0.005935 & 0.005543 \\
\hline 7 & ICBP & 0.004248 & 0.342231 & 0.005935 & 0.004825 \\
\hline 8 & INCO & 0.004248 & 1.022320 & 0.005935 & 0.005973 \\
\hline 9 & INTP & 0.004248 & 0.731518 & 0.005935 & 0.005482 \\
\hline 10 & JSMR & 0.004248 & 0.661702 & 0.005935 & 0.005364 \\
\hline 11 & KLBF & 0.004248 & 0.790906 & 0.005935 & 0.005582 \\
\hline 12 & MNCN & 0.004248 & 0.313952 & 0.005935 & 0.004777 \\
\hline 13 & PTBA & 0.004248 & 0.152152 & 0.005935 & 0.004504 \\
\hline 14 & TLKM & 0.004248 & -0.010214 & 0.005935 & 0.004230 \\
\hline 15 & UNTR & 0.004248 & 0.475537 & 0.005935 & 0.005050 \\
\hline 16 & UNVR & 0.004248 & 0.639055 & 0.005935 & 0.005326 \\
\hline 17 & WIKA & 0.004248 & 1.263023 & 0.005935 & 0.006379 \\
\hline \hline Source: Ms. Excel (data processed). & & &
\end{tabular}

\section{b. Security Market Line}

Security Market Line (SML) is a graph describing the CAPM model. The line in the SML describes the relationship between the value of the expected return and the systematic risk shown in beta $(\beta)$. Higher the stock beta value, will higher the sensitivity level of individual stocks to market developments. The following is a graphical form of the 17 companies included in the LQ45 index.

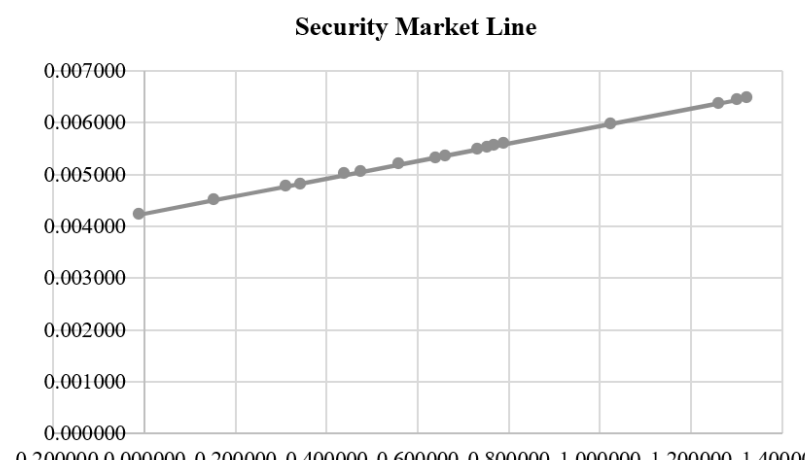

Fig. 3. Security Market Line.

The point represented by the beta and expected return of each LQ45 stock index increases. The right of the point of the line, the more the point will rise. This shows that the higher the expected return, the higher the stock beta value. In other words, if the size of the expected return is getting bigger, then investors must face a big risk, and vice versa.

c. Efficient Portfolio Establishment

Stock is efficient if the stock has an individual return value that is greater than the expected return rate of the stock [Ri > E (Ri)]. On the other hand, a stock is said to be inefficient if the stock has an individual return value that is smaller than the value of the expected return on the stock $[\mathrm{Ri}<\mathrm{E}(\mathrm{Ri})]$. The higher $[\mathrm{Ri}>\mathrm{E}(\mathrm{Ri})]$, the more profitable the efficient stock will be. The following is a list of stocks that are considered efficient and inefficient.

TABLE IX: LIST OF EFFICIENT AND INEFFICIENT SHARES

\begin{tabular}{|c|c|c|c|c|c|}
\hline $\begin{array}{l}\text { Stock } \\
\text { Code }\end{array}$ & $\mathbf{R i}$ & $\mathbf{E}(\mathbf{R i})$ & $\mathbf{R i}-\mathbf{E}(\mathbf{R i})$ & Result & Evaluation \\
\hline BBCA & 0.024622 & 0.004994 & 0.019627 & $\mathrm{Ri}>\mathrm{E}(\mathrm{Ri})$ & Efficient \\
\hline BBNI & 0.016436 & 0.006481 & 0.009955 & $\mathrm{Ri}>\mathrm{E}(\mathrm{Ri})$ & Efficient \\
\hline BBRI & 0.023458 & 0.005519 & 0.017939 & $\mathrm{Ri}>\mathrm{E}(\mathrm{Ri})$ & Efficient \\
\hline BBTN & 0.014189 & 0.006444 & 0.007745 & $\mathrm{Ri}>\mathrm{E}(\mathrm{Ri})$ & Efficient \\
\hline BMRI & 0.013524 & 0.005195 & 0.008329 & $\mathrm{Ri}>\mathrm{E}(\mathrm{Ri})$ & Efficient \\
\hline GGRM & 0.008409 & 0.005543 & 0.002866 & $\mathrm{Ri}>\mathrm{E}(\mathrm{Ri})$ & Efficient \\
\hline ICBP & 0.009029 & 0.004825 & 0.004204 & $\mathrm{Ri}>\mathrm{E}(\mathrm{Ri})$ & Efficient \\
\hline INCO & 0.017460 & 0.005973 & 0.011488 & $\mathrm{Ri}>\mathrm{E}(\mathrm{Ri})$ & Efficient \\
\hline INTP & 0.019171 & 0.005482 & 0.013689 & $\mathrm{Ri}>\mathrm{E}(\mathrm{Ri})$ & Efficient \\
\hline JSMR & 0.009445 & 0.005364 & 0.004081 & $\mathrm{Ri}>\mathrm{E}(\mathrm{Ri})$ & Efficient \\
\hline KLBF & 0.001800 & 0.005582 & -0.003782 & $\mathrm{Ri}<\mathrm{E}(\mathrm{Ri})$ & Inefficient \\
\hline MNCN & 0.003373 & 0.004777 & -0.001405 & $\mathrm{Ri}<\mathrm{E}(\mathrm{Ri})$ & Inefficient \\
\hline PTBA & 0.012271 & 0.004504 & 0.007767 & $\mathrm{Ri}>\mathrm{E}(\mathrm{Ri})$ & ient \\
\hline TLKM & 0.005097 & 0.004230 & 0.000867 & $\mathrm{Ri}>\mathrm{E}(\mathrm{Ri})$ & Efficient \\
\hline UNTR & 0.007309 & 0.005050 & 0.002259 & $\mathrm{Ri}>\mathrm{E}(\mathrm{Ri})$ & Efficient \\
\hline UNVR & 0.003180 & 0.005326 & -0.002145 & $\mathrm{Ri}<\mathrm{E}(\mathrm{Ri})$ & Inefficient \\
\hline WIKA & 0.005586 & 0.006379 & -0.000793 & $\mathrm{Ri}<\mathrm{E}(\mathrm{Ri})$ & Inefficient \\
\hline
\end{tabular}

Source: Ms. Excel (data processed).

Based on the table above, of the 17 company shares in the LQ45 index studied there are 13 company shares that are efficient shares and are included inefficient portfolios based on the Capital Asset Pricing Model method. Based on the difference, the most profitable efficient shares are BBCA (Bank Central Asia Tbk.) And the least profitable shares are TLKM (Telkom Indonesia Tbk.).

\section{E. Portfolio Performance Evaluation}

The portfolios that have been formed are evaluated using portfolio performance measures consisting of the Sharpe index, Tryenor index and Jensen index. The Sharpe index is 
calculated as the interval between expected return and risk free rate (excess return) divided by the standard deviation. Treynor index is calculated by dividing the stock's expected return and risk free rate (excess return) divided by the stock beta. The Jensen index is calculated by the rate of return minus the rate of expected return.

The results of these three indices provide an overview of the performance of stocks in stock portfolios that are formed for investors before making investment decisions. The following is the calculation result of the Sharpe index, Treynor index, and Jensen index for portfolios formed by the Single Index Model (SIM) and Capital Asset Pricing Model (CAPM) methods. Sharpe, Treynor, and Jensen Portfolio Index with the Single Index Model (SIM) Method

TABLE X: SHARPE INDEX, TREYNOR INDEX, AND JENSEN INDEX OF PORTFOLIO WITH SINGLE INDEX MODEL METHOD

\begin{tabular}{|c|c|c|c|c|}
\hline No & $\begin{array}{c}\text { Stock } \\
\text { Code }\end{array}$ & $\begin{array}{c}\text { RVA } \\
\text { (Sharpe) }\end{array}$ & $\begin{array}{c}\text { RVO } \\
\text { (Treynor) }\end{array}$ & $\begin{array}{c}\boldsymbol{\alpha} \\
\text { (Jensen) }\end{array}$ \\
\hline 1 & PTBA & 0.067594 & 0.052732 & 0.007767 \\
\hline 2 & BBCA & 0.486309 & 0.046040 & 0.019627 \\
\hline 3 & BBRI & 0.331426 & 0.025499 & 0.017939 \\
\hline 4 & INTP & 0.141682 & 0.020400 & 0.013689 \\
\hline 5 & BMRI & 0.223375 & 0.016524 & 0.008329 \\
\hline 6 & ICBP & 0.110896 & 0.013970 & 0.004204 \\
\hline \multicolumn{2}{|c|}{ Average } & 0.226880 & 0.029194 & 0.011926 \\
\hline
\end{tabular}

Source: Ms. Excel (data processed).

Based on the table above, all the ratios for the Sharpe index, Treynor index, and Jensen index for each share in the portfolio arranged by the Single Index Model have a positive value. This means that the six shares of the company are feasible to purchase as measured by unsystematic risk (standard deviation), systematic risk (beta), and alpha benchmarks. The value generated by each share with the three indices shows the amount of performance of each share for a portfolio that is calculated from each benchmark. According to the Sharpe index calculation results, the rank order of the company's shares from the top is BBCA, BBRI, BMRI, INTP, ICBP, and finally PTBA. The average of the resulting Sharpe index is 0.226880 . The average positive Sharpe index indicates good performance from an unsystematic risk point of view. The greater the Sharpe index value, the better the portfolio performance.

According to the results of the Treynor index calculation, the rank order of the company's shares from the top is PTBA, BBCA, BBRI, INTP, BMRI, and finally ICBP. The average Treynor index resulting from this optimal portfolio is 0.029194. The average positive Treynor index means that the performance of the portfolio is good from a systematic risk point of view. The greater the Treynor index value, the better the performance of a portfolio.

Based on the results of Jensen's calculations, the ranking of shares from the top is BBCA, BBRI, INTP, BMRI, PTBA, and the last is ICBP. The average Jensen index of the optimal portfolio that was formed was 0.011926. The average positive Jensen index reflects that the financial managers of the company produce better performance than the market index.

Based on the table below, the Sharpe index calculation results show a positive value on all stocks including portfolios using the CAPM method. This means that all of the included shares are worth buying. The largest share Sharpe index value is BBCA (Bank Central Asia Tbk.), Which is 0.486309 . Meanwhile, the stocks with the smallest Sharpe index were TLKM (Telkom Indonesia Tbk.) Shares of 0.015366. The average Sharpe index formed from the efficient portfolio is 0.145802 . The average positive Sharpe index indicates that the portfolio performance is good from an unsystematic risk point of view.

TABLE XI: SHARPE INDEX, TREYNOR INDEX, AND JENSEN INDEX OF PORTFOLIO WITH CAPITAL ASSET PRICING MODEL METHOD

\begin{tabular}{ccccc}
\hline \hline No & $\begin{array}{c}\text { Stock } \\
\text { Code }\end{array}$ & $\begin{array}{c}\text { RVA } \\
\text { (Sharpe) }\end{array}$ & $\begin{array}{c}\text { RVO } \\
\text { (Treynor) }\end{array}$ & $\begin{array}{c}\boldsymbol{\alpha} \\
\text { (Jensen) }\end{array}$ \\
\hline 1 & BBCA & 0.486309 & 0.046040 & 0.019627 \\
\hline 2 & BBNI & 0.149819 & 0.009207 & 0.009955 \\
\hline 3 & BBRI & 0.331426 & 0.025499 & 0.017939 \\
\hline 4 & BBTN & 0.094032 & 0.007636 & 0.007745 \\
\hline 5 & BMRI & 0.223375 & 0.016524 & 0.008329 \\
\hline 6 & GGRM & 0.070744 & 0.005419 & 0.002866 \\
\hline 7 & ICBP & 0.110896 & 0.013970 & 0.004204 \\
\hline 8 & INCO & 0.095101 & 0.012924 & 0.011488 \\
\hline 9 & INTP & 0.141682 & 0.020400 & 0.013689 \\
\hline 10 & JSMR & 0.068538 & 0.007854 & 0.004081 \\
\hline 11 & PTBA & 0.067594 & 0.052732 & 0.007767 \\
\hline 12 & TLKM & 0.015366 & -0.083196 & 0.000867 \\
\hline 13 & UNTR & 0.040541 & 0.006438 & 0.002259 \\
\hline Average & $\mathbf{0 . 1 4 5 8 0 2}$ & $\mathbf{0 . 0 1 0 8 8 1}$ & $\mathbf{0 . 0 0 8 5 2 4}$ \\
\hline \hline
\end{tabular}

Source: Ms. Excel (data processed).

In the Treynor index, 12 company stocks included in the portfolio using the CAPM method have positive values, namely BBCA, BBNI, BBRI, BBTN, BMRI, GGRM, ICBP, INCO, INTP, JSMR, PTBA, and UNTR stocks. purchased. Meanwhile, one company share has a negative value, namely TLKM (Telkom Indonesia Tbk.), Indicating that it is not feasible to buy from a systematic risk aspect. The average Treynor index value formed by the CAPM method is 0.010881 . The positive average value of the Treynor index reflects that the portfolio performance is good from a systematic risk point of view.

According to the results of the Jensen index calculation, all stocks included in the portfolio using the CAPM method have a positive value. This means that all shares in this portfolio are worth buying. The largest Jensen index value is BBCA (Bank Central Asia Tbk.), Which is 0.019627. Meanwhile, the stocks with the smallest Jensen index were TLKM (Telkom Indonesia Tbk.) Shares of 0.000867. The average Jensen index that was formed was 0.008524 . This means that the average positive value of the Jensen index illustrates that the financial managers of companies formed in this efficient portfolio produce better performance than the market index.

\section{F. Discussion}

\section{Single Index Model}

Based on the results of research analysis through 17 companies included in the LQ45 index 2017-2019 which were used as research samples, it shows that there are 6 stocks in the optimal portfolio because the ERB results of stocks are greater than $\mathrm{Ci}$. The composition for the optimal portfolio fund consists of Bukit Asam Tbk. (PTBA) 2.66\%, Bank Central Asia Tbk. (BBCA) at $63.05 \%$, Bank Rakyat Indonesia (BBRI) at 23.04\%, Indocement Tunggal Prakarsa Tbk. $2.99 \%$, Bank Mandiri Tbk. amounting to $8.04 \%$, and Indofood CBP Sukses Makmur Tbk. by $0.22 \%$. 
The level of expected return portfolio $[\mathrm{E}(\mathrm{Rp})]$ from the optimal portfolio is $2.29 \%$. Meanwhile, the optimal portfolio risk level is $0.32 \%$. In other words, that the optimal portfolio of stocks that is formed has a level of risk that is much smaller than the level of portfolio expected return.

The results of this study are supported by research from Yuliansyah (2018) which explains that investors can have a higher level of portfolio profit than the level of risk of their portfolios. This also supports Anggraeni's (2018) research where by diversifying stocks into portfolios, it can increase profits and reduce the level of risk that will be faced. Oktaviani and Wijayanto's (2015) research also supports this research that each stock in the optimal portfolio has a different proportion due to differences in stock prices, the level of profit and individual risk that accompany these stocks. This research produces 6 stocks which are classified as optimal portfolios with the expected profit level of the portfolio is greater than the portfolio risk level. It can be concluded that creating a portfolio with a predetermined proportion of shares can produce an optimal level of portfolio expected return with a minimum level of risk so that it will make it easier for investors before investing.

\section{Capital Asset Pricing Model}

Based on the table above, the Sharpe index calculation results show a positive value for all stocks. This means that all of the included shares are worth buying. The highest share Sharpe index value is BBCA (Bank Central Asia Tbk.), which is 0.486309 and the smallest is TLKM (Telkom Indonesia Tbk.) which is of 0.015366 . The average efficient portfolio Sharpe index is 0.145802 . The average positive Sharpe index indicates that the portfolio performance is good from an unsystematic risk point of view.

In the Treynor index, 12 company stocks that are included in the efficient portfolio have a positive value, namely BBCA, BBNI, BBRI, BBTN, BMRI, GGRM, ICBP, INCO, INTP, JSMR, PTBA, and UNTR shares which means that the 12 company shares are worth buying. Meanwhile, one share has a negative value, namely TLKM (Telkom Indonesia Tbk.), Indicating that it is not likely to buy from a systematic risk aspect. The average Treynor index value is 0.010881 . The positive average value of the Treynor index reflects that the portfolio performance is good from a systematic risk point of view.

According to the Jensen index results, all stocks included in the portfolio have a positive value. This means that all shares in this portfolio are worth buying. The largest Jensen index value is BBCA (Bank Central Asia Tbk.), Which is 0.019627. Meanwhile, the stocks with the smallest Jensen index were TLKM (Telkom Indonesia Tbk.) Shares of 0.000867 . The average Jensen index that was formed was 0.008524 . This means that the average positive value of the Jensen index illustrates that the financial managers of companies formed in this efficient portfolio produce better performance than the market index.

\section{Portfolio Performance Evaluation}

The evaluation of the optimal portfolio using the Single Index Model results in a positive average value of the Sharpe index, Treynor index, and Jensen index. It means the performance of the optimal portfolio is good, so that it can be considered by investors to invest in the optimal portfolio of stocks with Single Index Model method. According to the Sharpe index of optimal portfolios, the best stock performance is produced by BBCA (Bank Central Asia Tbk.) And the smallest stock performance is produced by PTBA (Bukit Asam Tbk.). According to the Treynor index for optimal portfolios, the best stock performance is produced by PTBA (Bukit Asam Tbk.) And the smallest stock performance is produced by ICBP (Indofood CBP Tbk.). According to the Jensen index of optimal portfolios, the best stock performance is produced by BBCA (Bank Central Asia Tbk.) And the smallest stock performance is produced by ICBP (Indofood CBP Tbk.).

In an efficient portfolio using Capital Asset Pricing Model, the average value of the Sharpe index, Treynor index, and Jensen index is positive. This reflects that the efficient portfolio formed produces good performance and can be considered by investors. According to the Sharpe index, the best performance in an efficient portfolio is BBCA (Bank Central Asia Tbk.) and the smallest stock performance is TLKM (Telkom Indonesia Tbk.). According to the Treynor index, the best performance in an efficient portfolio is PTBA (Bukit Asam Tbk.) and the smallest performance is GGRM (Gudang Garam Tbk.). According to the Jensen index, the best performance in an efficient portfolio is BBCA (Bank Central Asia Tbk.) and the smallest performance is TLKM (Telkom Indonesia Tbk.).

This is supported by Ardi's research (2016) that portfolios that have positive values from the Sharpe index, Treynor index, and Jensen index describe good stock performance. Each index produces a different characteristic number value due to the variable factors used. This supports the research conducted by Narulita (2016) that the choice of stock performance measurement is returned to investors or capital market players using these index.

\section{CONCUSIONS}

\section{A. Conclusion}

Based on the results of calculations and analysis of previous research, there are several conclusions:

a. The optimal portfolio using the Single Index Model method consists of 6 stocks with a proportion of funds, namely shares of PTBA, BBCA, BBRI, INTP, BMRI, and ICBP. The level of expected return for this portfolio is $2.29 \%$ and the level of portfolio risk is $0.32 \%$. This means that the portfolio can diversify stocks so that investors can obtain the maximum level of expected return with a minimum level of risk.

b. An efficient portfolio using the Capital Asset Pricing Model method consists of 13 company stocks. The stocks referred to are BBCA, BBNI, BBRI, BBTN, BMRI, GGRM, ICBP, INCO, INTP, JSMR, PTBA, TLKM, and UNTR shares. This provides a decision to buy or hold stocks efficiently because the trend in stock prices will tend to increase so that investors will benefit. For stocks that are classified as inefficient, the decision that investors need to make is not to buy or sell these shares because it will result in losses for investors if they buy or not immediately sell inefficient shares. 
c. Evaluation of portfolio performance is using the Sharpe index, Treynor index, and Jensen index. The higher the value of an index, the better the performance of the stock. According to the Sharpe index, the ranking from the highest of the Single Index Model is BBCA, BBRI, BMRI, INTP, ICBP, and PTBA. Meanwhile, the Capital Asset Pricing Model is BBCA, BBRI, BMRI, BBNI, INTP, ICBP, INCO, BBTN, GGRM, JSMR, PTBA, UNTR, and TLKM. According to the Treynor index, the rankings on the Single Index Model are PTBA, BBCA, BBRI, INTP, BMRI, and ICBP. Meanwhile, the Capital Asset Pricing Model, namely PTBA, BBCA, BBRI, INTP, BMRI, ICBP, INCO, BBNI, JSMR, BBTN, UNTR, and GGRM. According to the Jensen index, the highest to lowest ranks from the Single Index Model are BBCA, BBRI, INTP, BMRI, PTBA, and ICBP. Meanwhile, the Capital Asset Pricing Model, namely BBCA, BBRI, INTP, INCO, BBMI, BMRI, PTBA, BBTN, ICBP, JSMR, GGRM, UNTR, and TLKM.

\section{B. Research Limitation}

In this study, there are still some limitations and drawbacks theoretically and technically. The limitations and shortcomings referred to are:

a. Daily stock prices are always changing, so the secondary data to form a portfolio using the Single Index Model and Capital Asset Pricing Model (CAPM) method is not perfect because the average is not the average daily stock price change.

b. This study uses company stocks on the LQ45 index during the study period with a predetermined sampling technique, even though there are stocks that come out and enter the LQ45 index list at each period so that it is said to be less representative of the overall performance of the LQ45 index shares.

\section{Suggestion}

Based on the results of calculations and discussion analysis, as well as the conclusions that have been made, the suggestions that can be given are as follows:

a. Theoretically

It is recommended for further researchers to analyze the formation of investment portfolios on other stocks that have potential with other portfolio methods such as the Arbitrage Pricing Theory (APT) method, the Black-Litterman method, or the portfolio method.

b. Practically

In addition to this research being a reference and additional information for investors, investors are expected to consider the good side of the rate of return and the level of risk before investing.

\section{REFERENCES}

[1] Ardi, "Stock Portfolio Performance Analysis with the Sharpe, Jensen and Treynor Method (15 Shares on the Indonesia Stock Exchange for the Period of January-February 2016)", Journal Research Gate, pp. 67, 2016.

[2] Rokhmahtussa'dyah, and Suratman, Investment Law and Capital Markets, Jakarta, ID: Sinar Grafika, 2017, pp. 3.

[3] Bank Indonesia. (2020). Certificate of Bank Indonesia (SBI) in $2017-$ 2019. Bank Indonesia. [Online]. Available: www.bi.go.id.

[4] CNBC Indonesia. (2019). Single Investor Identification. CNBC Indonesia. [Online]. Available: www.cnbcindonesia.com.
[5] Tandelilin, Capital Market: Portfolio Management and Investasment, Yogyakarta, ID: PT Kanisius, 2017, pp. 92-164.

[6] D. Zein, et. al., Optimizing of ISSI Stock Portfolio using Single Index Models in 2013-2017, Knowledge E Publishing, DOI 10.18502/kss.v3i13.4215, 2019.

[7] Yuliansyah, "Comparison of Portfolio Formation Using the Single Index Method and the Capital Asset Pricing Model (CAPM)" S.E. thesis, Maulana Malik Ibrahim State Islamic University Malang, Malang, Indonesia, 2018.

[8] Finance Yahoo. (2020). Stock Closing Price in 2017-2019. Yahoo [Online]. Available: finance.yahoo.com.

[9] A.-S. Dewi and D. P. Vijaya, Investment and Indonesia Capital Market, Depok: PT RajaGrafindo Persada, 2018, pp. 2-160.

[10] J. Guinan, Investopedia: Easy Ways to Understanding Investment. Jakarta: Hikmah Publisher (PT Mizan Publika), 2010, pp. 273.

[11] J. Hartono, Portfolio Theory and Practice with Excel. Jakarta: Salemba Empat, 2014, pp. 221-228.

[12] J. Suteja and A. Gunardi. Investment Management and Portfolio. Bandung: PT Refika Aditama, 2016, pp. 2.

[13] Kustodian Sentra Efek Indonesia. (December 2019). Innovation For The Convenience Of Transactions In The Capital Market. Kustodian Sentra Efek Indonesia. [Online]. Available: www.ksei.co.id.

[14] M. L. Wardiyah, Money Market and Capital Market Management, Bandung: CV Pustaka Setia, 2017, pp. 13.

[15] M. Samsul. Capital Markets and Portfolio Management Issue 2 Jakarta: Erlangga Publisher, 2015, pp. 304-351.

[16] M. Yunus, "Analysis of the Optimal Portfolio Formation of Shares Using a Single Index Model on the Indonesia Stock Exchange for Investment Decision Making" S.E. thesis, Faculty of Economy, Muhammadiyah University of Yogyakarta, Yogyakarta, Indonesia, 2016.

[17] Oktaviani, B. N. and Wijayanto, A., Single Index Model Application in the Formation of Optimal Portfolios of LQ45 Shares and the Jakarta Islamic Index, Journal of Management Analysis 4, vol. 1, 2015, pp. 198.

[18] S. Hidayat, "Comparative Analysis of Optimal Portfolio Shares Formation Using the Single Index Model and the Capital Asset Pricing Model" S.E. thesis, Faculty of Business and Economy, Widyatama University, Bandung, Indonesia, 2016.

[19] S. Kholishoh, S. Mulyantini, dan M. Miftah. (January 2020). Efficient Portfolio Analysis with CAPM and RVAR Methods as Preference for Investment Decisions on JII Index Stocks for the 2017-2018 Period. Journal of UPNVJ. [Online]. pp. 1240-1241. Available: www.ocs.upnvj.ac.id.

[20] S. Narulita, Stock Performance Analysis Using Sharpe, Treynor and Jensen Methods in Telecommunication Companies, Journal UNTAG, vol. 4, 2016, pp. 692

[21] T. R. Anggraeni, Optimizing Financing Sharia Bank Through the Formation of Optimal Portfolio with Single Index Model, International Conference on Islamic Finance Journal, Economics and Business, vol. 2018, 2018, pp. 269-270.

[22] Zulfikar, Introduction to the Capital Market with a Statistical Approach, Yogyakarta: Deepublish Publisher, 2016.

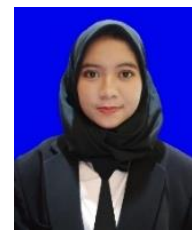

Nurul Avriyanti Sholehah got her bachelor from Faculty of Economy and Business, Universitas Pembangunan Nasional Veteran Jakarta (Finance Management Studies) and graduated with distinction (cumlaude, GPA 3.76 out of 4.00).

During as a student, she got many experience by organization or company as like MC, Head Departement, Student Ambassador, etc. After graduate, she is join to Financing Company as Assistant Manager, Graphic Designer Freelancer of Non-Government Organization, and then Content Creator in Financial Technology Company. 